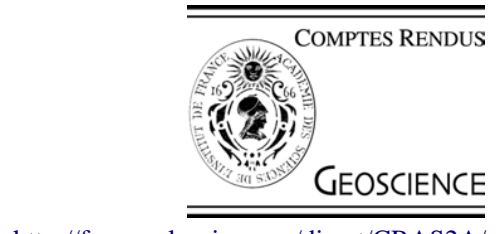

http://france.elsevier.com/direct/CRAS2A/

Tectonics / Tectonique

\title{
Neotectonics and seismic hazard assessment in Hengchun Peninsula, southern Taiwan
}

\author{
Claudio Vita-Finzi ${ }^{\mathrm{a}, *}$, Jiun-Chuan Lin ${ }^{\mathrm{b}}$ \\ ${ }^{a}$ Department of Mineralogy, Natural History Museum, Cromwell Rd, London SW7 5BD, UK \\ b Department of Geography, National Taiwan University, Roosevelt Rd, Taipei 106, Taiwan, ROC
}

Received 26 April 2004; accepted after revision 18 April 2005

Available online 20 July 2005

Written on invitation of the Editorial Board

\begin{abstract}
Neotectonic data may indicate whether stored elastic energy will be dissipated or released destructively. The Hengchun Peninsula of Taiwan is the southern extremity of the Central Range of Taiwan and thus an emergent part of the accretionary wedge resulting from subduction of Eurasia beneath the Philippine Sea plate at the Manila Trench. Radiocarbon dating of fossil shorelines on the peninsula shows that it has been uplifted at an average rate of $3.8 \mathrm{~mm} / \mathrm{yr}$ during the Holocene. About $1 / 3$ of the uplift is due to deformation along the Hengchun reverse fault but, in contrast with the Chelungpu and other low angle reverse faults west of the Central Range, it accommodates strain principally by aseismic creep. To cite this article: C. Vita-Finzi, J.-C. Lin, C. R. Geoscience 337 (2005).

(C) 2005 Académie des sciences. Published by Elsevier SAS. All rights reserved.
\end{abstract}

\section{Résumé}

Néotectonique et évolution des dangers sismiques dans la péninsule de Hengchun, Sud de Taiwan. Les données de la néotectonique contribuent à déterminer si l'énergie élastique accumulée est dissipée de façon destructive ou progressivement. La péninsule de Hengchun constitue l'extrémité méridionale de la chaîne centrale de Taiwan et, par conséquent, un morceau émergé du prisme d'accrétion produit par la subduction de l'Eurasie sous la plaque de la mer des Philippines dans la fosse de Manille. La datation au carbone 14 des rivages fossiles de la péninsule montre qu'elle a été soulevée à une vitesse moyenne de $3,8 \mathrm{~mm} \mathrm{an}^{-1}$. Un tiers du mouvement se produit sur la faille inverse de Hengchun, mais, contrairement à la faille de Chelungpu et aux autres chevauchements peu inclinés de l'Ouest de la chaîne centrale, cette faille de Hengchun absorbe la plus grande part de la déformation compressive par glissement aséismique. Pour citer cet article : C. Vita-Finzi, J.-C. Lin, C. R. Geoscience 337 (2005). ( 2005 Académie des sciences. Published by Elsevier SAS. All rights reserved.

Keywords: Taiwan; Seismicity; Neotectonics; ${ }^{14} \mathrm{C}$ Dating; Geodesy

Mots-clés : Taiwan; Sismicité ; Néotectonique ; Datation au carbone 14 ; Géodésie

\footnotetext{
* Corresponding author.

E-mail address: cvitafinzi@aol.com (C. Vita-Finzi).
} 


\section{Introduction}

The assessment of seismic hazard is generally based on one of two approaches. In stochastic studies, the aim is to estimate the probability of occurrence of earthquakes of different magnitude at the location in question during a specified period. Deterministic assessment deals primarily with the largest credible earthquake at the site during the current tectonic regime. Seismic zoning, being concerned with the effects rather than the causes of the seismicity, will therefore tend to draw on both schemes. In the USSR, for example, zoning combined seismological, geological and terrain factors, and some local building codes in the USA take account of probabilistic studies of peak ground velocity. Other procedures are more firmly rooted in structural geology albeit with a historical component. The seismic gap model, which is largely confined to subduction settings, identifies parts of the potential seismogenic zone that has not experienced a significant event during the period of record. The asperity model is effectively its converse, as it seeks locations along such a zone where earthquakes have occurred repeatedly.

A third approach is to define belts of heightened deformation within which seismicity is likely. It has been applied to peninsular India on the basis of intraplate buckling [16]. An earlier version of this proposal was advanced for Taiwan; it identified structural belts where fault geometry was favourable to strain release in major earthquakes [15]. One of the structural units that was analysed in order to assess variations in potential seismicity in Taiwan was the Hengchun Peninsula, the southern extremity of Taiwan (Fig. 1). The primary aim of this paper is to establish how far that assessment needs to be modified by new information on the Holocene uplift of the peninsula.

\section{The Hengchun Peninsula}

South of Taiwan the Eurasian plate is being overridden by the Philippine Sea plate at the Manila Trench $[1,5]$. The resulting accretionary wedge is marked by the Hengchun Ridge, which extends onto Taiwan as the Central Range and the fold-and-thrust zone west of it [11] (Fig. 1). In the southern part of the island, these two belts are separated by the Chaouchou thrust fault

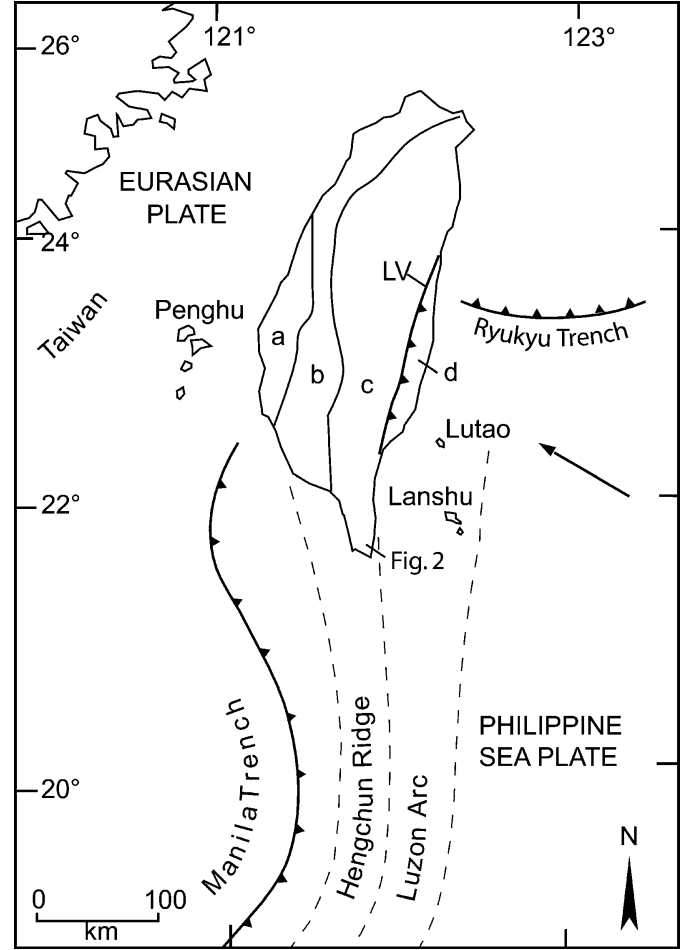

Fig. 1. Structural setting of the Hengchun Peninsula.

Fig. 1. Cadre structural de la Péninsule de Hengchun.

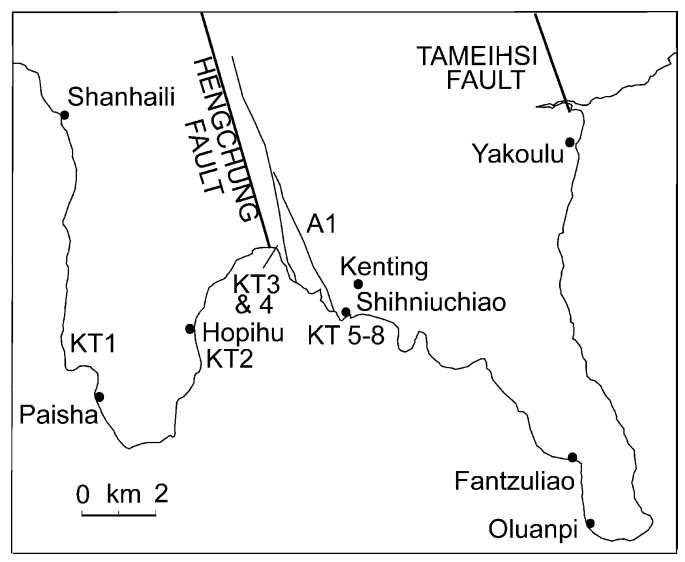

Fig. 2. The Hengchun Peninsula. Places mentioned in text.

Fig. 2. Péninsule de Hengchun. Lieux cités dans le texte.

[7], which extends into the Hengchun Peninsula as the Hengchun fault (Fig. 2). The Miocene-Pleistocene strata that make up the peninsula display other reverse faults and recumbent folds. 
Convergence of $\sim 86 \mathrm{~mm} \mathrm{yr}^{-1}$ between the Philippine Plate and Eurasia is oblique at about $307^{\circ}$ [11], and the suture, which is marked by the Longitudinal Valley, propagates southwards. The GPS evidence for 1990-1994 [19] indicates rapid shortening at the Longitudinal Valley $\left(29.6 \mathrm{~mm} \mathrm{yr}^{-1}\right)$ and the fold-andthrust belt (locally as high as $20 \mathrm{~mm} \mathrm{yr}^{-1}$ ), and extension both at the Coastal Range $\left(0.6 \mathrm{~mm} \mathrm{yr}^{-1}\right)$ and at the Central Range $\left(8.6 \mathrm{~mm} \mathrm{yr}^{-1}\right)$. Levelling indicates uplift of the Central Range by $36-42 \mathrm{~mm} \mathrm{yr}^{-1}$, compared with long-term rates of 7.15-15 $\mathrm{mm} \mathrm{yr}^{-1}$ derived from fission-track and K/Ar dating [9].

Holocene palaeoshores on the east coast of Taiwan, in conjunction with microseismic records, point to distributed deformation on imbricate reverse faults within the Coastal Range [17], which could well account for geodetic evidence of extension by giving rise to anticlinal folding above blind faults [6]. Age/height data for the islands of Lanhsu and Lutao point to slow $\left(1.3 \mathrm{~mm} \mathrm{yr}^{-1}\right)$ uplift of the former until about $\sim 5000 \mathrm{yr}$ ago and continuing, more rapid $\left(2.6 \mathrm{~mm} \mathrm{yr}^{-1}\right.$ ) uplift of the latter; the difference in tectonic history is consistent with a reduction in the rate of uplift as the plate suture closes progressively southward [15]. In contrast, the Longitudinal valley combines reverse faulting with aseismic strike slip, and in the fold-and-thrust western foothills relatively low angle structures favour strain release in large earthquakes of which the 1999 Chi-Chi earthquake is a prime example.

To judge from the instrumental evidence, the Hengchun area at the southern extremity of the Cen- tral Range experiences few significant earthquakes, although two substantial events have been located south of it: the Hengchun earthquake of 1959.08.15 $\left(21^{\circ} 42^{\prime} \mathrm{N}, 121^{\circ} 18^{\prime} \mathrm{E}, M=7.1\right)$, and the event of 1955.4.4 $\left(21^{\circ} 48^{\prime} \mathrm{N}, 121^{\circ} \mathrm{E}, M=6.6\right)$. Both are associated with the belt of active seismicity along the Luzon arc [10], that is the volcanic arc at the rear of the accretionary complex.

\section{Uplift history}

Shoreline data for the Hengchun Peninsula reported in the classic study by Liew and Lin [8] indicated a rate of uplift of about $4.7 \mathrm{~mm} \mathrm{yr}^{-1}$ [15]. As in the Coastal Range, geodetic evidence for extension could be explained by near-surface folding above a series of reverse faults. Indeed, Liew and Lin [8] describe a folded raised beach that is cut near its culmination by a thrust fault ('A1') striking $\mathrm{N} 20^{\circ}-30^{\circ} \mathrm{W}$ and dipping steeply eastward (Fig. 2). They took their A1 fault to be part of the Hengchun fault system; the 1/50000 geological map of the Hengchun Peninsula [2] shows the Hengchun fault as a high-angle thrust dipping east, parallel to and about $1.5 \mathrm{~km}$ west of the proposed location of A1 (Fig. 1). The Hengchun fault juxtaposes the Mio-Pliocene Kenting Formation with gently folded Pleistocene and Holocene alluvium, coral reef, siltstone and limestone. A second major reverse fault, this time with a westward dip (the Tameihsi Fault), crosses the coast at Yakoulu; to judge from published sections [2] the fault acted as backstop to a series of north-

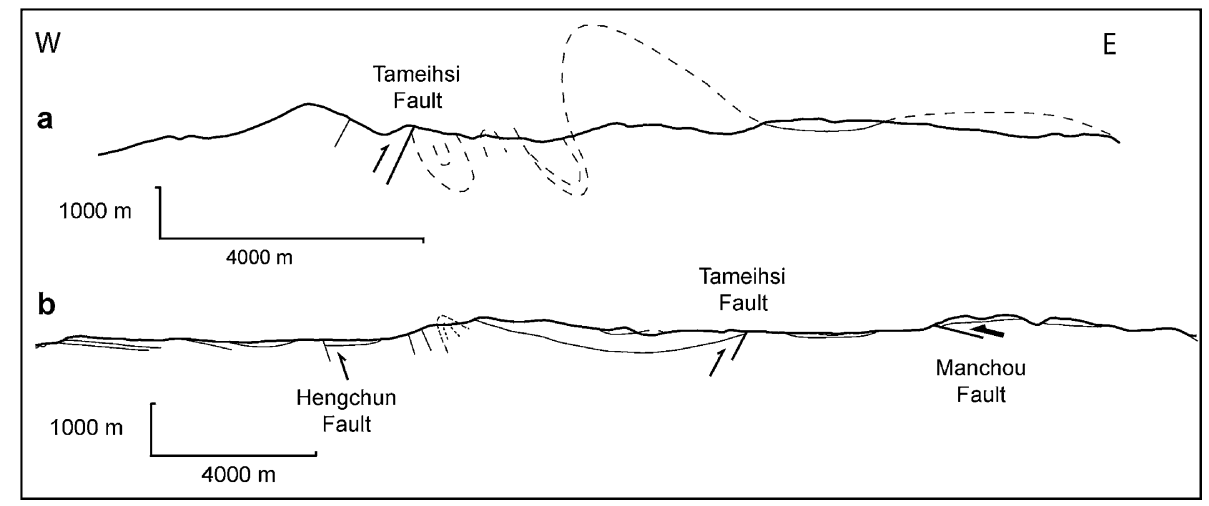

Fig. 3. Approximately east-west geological cross-sections for the Hengchun Peninsula at about (a) $24^{\circ} 51^{\prime}$ and (b) $24^{\circ} 38^{\prime}$. Based on [2].

Fig. 3. Coupes géologiques approximativement est-ouest de la péninsule de Hengchun à environ (a) $24^{\circ} 51^{\prime}$ et (b) $24^{\circ} 38^{\prime}$. D'après [2]. 
Table 1

${ }^{14} \mathrm{C}$ ages for the Hengchun Peninsula

Tableau 1

Âges carbone 14 relatifs à la péninsule de Hengchun

\begin{tabular}{|c|c|c|c|c|c|}
\hline Site & Elev. (m) & Corr. elev. $(\mathrm{m})^{1}$ & ${ }^{14} \mathrm{C}$ age (yr BP) & Cal. age ${ }^{2}$ (yr BP) & Source $^{3}$ \\
\hline Yakoulu & 10 & 9.5 & $3700 \pm 250$ & $3630 \pm 680$ & a \\
\hline \multirow{10}{*}{ Kenting } & 1 & 1 & $1580 \pm 20$ & $1165 \pm 250$ & a \\
\hline & 12 & 11 & $4310 \pm 120$ & $4430 \pm 375$ & a \\
\hline & 14 & 13.5 & $3900 \pm 125$ & $3885 \pm 355$ & a \\
\hline & 14 & 13.5 & $4040 \pm 120$ & $4080 \pm 650$ & a \\
\hline & 14 & 13.5 & $4600 \pm 400$ & $4820 \pm 1100$ & $\mathrm{a}$ \\
\hline & 20 & 20 & $5200 \pm 95$ & $5580 \pm 250$ & a \\
\hline & 20 & 20.5 & $5730 \pm 480$ & $6170 \pm 1140$ & a \\
\hline & 20 & 37 & $8410 \pm 155$ & $8920 \pm 475$ & $\mathrm{a}$ \\
\hline & 20 & 38.5 & $8660 \pm 155$ & $9055 \pm 715$ & a \\
\hline & 22 & 32 & $7810 \pm 155$ & $8310 \pm 290$ & a \\
\hline \multirow[t]{7}{*}{ Shihniuchiao } & 1.5 & 1.5 & $1710 \pm 110$ & $1275 \pm 230$ & $\mathrm{a}$ \\
\hline & 1.5 & 1.5 & $1780 \pm 115$ & $1325 \pm 260$ & a \\
\hline & 15 & 14.5 & $5000 \pm 300$ & $5325 \pm 770$ & a \\
\hline & 15 & 15.5 & $5670 \pm 140$ & $6100 \pm 350$ & $\mathrm{a}$ \\
\hline & 15 & 20 & $7050 \pm 145$ & $7555 \pm 260$ & a \\
\hline & 15 & 14 & $5000 \pm 400$ & $5325 \pm 1020$ & $\mathrm{a}$ \\
\hline & 15 & 40.5 & $9600 \pm 1000$ & $10300 \pm 2840$ & $\mathrm{a}$ \\
\hline KT5 & 17 & 38 & $8760 \pm 60$ & $9225 \pm 535$ & b (NTU-2636) \\
\hline KT6 & 17 & 23.5 & $8300 \pm 60$ & $8855 \pm 410$ & b (NTU-2637) \\
\hline KT & 1.5 & 7 & $7270 \pm 60$ & $7730 \pm 110$ & b (NTU-2643) \\
\hline KT8 & 0 & -0.5 & $4980 \pm 50$ & $5315 \pm 150$ & b (NTU-2644) \\
\hline Shanhaili & 12 & 11.5 & $4950 \pm 125$ & $5300 \pm 360$ & $\mathrm{a}$ \\
\hline Fantzuliao & 1 & 1 & $1300 \pm 120$ & $885 \pm 240$ & $\mathrm{a}$ \\
\hline KT1 & 3 & 17 & $6670 \pm 50$ & $7225 \pm 90$ & b (NTU-2640) \\
\hline KT2 & 6 & 5.5 & $5070 \pm 40$ & $5450 \pm 140$ & b (NTU-2641) \\
\hline KT3 & 6 & 6.5 & $5660 \pm 50$ & $6090 \pm 155$ & b (NTU-2642) \\
\hline KT4 & 2 & 2 & $1820 \pm 40$ & $1370 \pm 110$ & b (NTU-2649) \\
\hline
\end{tabular}

1 Elevations rounded to nearest $0.5 \mathrm{~m}$; calibrated ages expressed as \pm maximum error at 2 s.d. Glacioisostatic correction after W.R. Peltier (see text).

2 Age calibration using CALIB Rev. 4.1.2 (1999): see [13]. No correction for fractionation as $\delta^{13} \mathrm{C}$ not determined. For marine reservoir effects, see text. The regional average for the western sub-tropical Pacific is $-94 \pm 46 \mathrm{yr}$ [13]

3 a: [8] and sources therein; b: National Taiwan University radiocarbon laboratory.

south folds in the Miocene clastics that make up much of the peninsula (Fig. 3). Both faults can be traced north to the Tulungyan Fault, which forms the western boundary of the Central Range [5].

In order to evaluate the extent of Holocene deformation, the existing twenty age/height values $[8,15]$, including three which had been unaccountably omitted in the earlier account, were supplemented by a further eight on samples collected for the present study. The ages were calibrated using the 1999 (Rev. 4.1.2) version of the program by Stuiver and Reimer [13] after allowing for the small marine reservoir correction value of $-17 \mathrm{yr}$ proposed by P. Reimer for the western
Pacific (http://radiocarbon.pa.qub.ac.uk/marine/). The elevations were adjusted for the glacio-hydroisostatic component (as before) using data derived by interpolation between sea-level curves for $22^{\circ} \mathrm{N} 121^{\circ} \mathrm{E}$ and $25^{\circ} \mathrm{N} 122^{\circ} \mathrm{E}$ by Prof. W.R. Peltier (July 1997, pers. commun.). As most of the samples consisted of redeposited shells and coral fragments, the ages must be considered to be maximum values for the sample sites.

Table 1 lists the various age/height values. The enlarged dataset supports the earlier estimate of Holocene uplift, as the least squares line indicates an emergence rate of $3.8 \mathrm{~mm} \mathrm{yr}^{-1}\left(r^{2}=0.71\right)$ (Fig. $\left.4 \mathrm{a}\right)$. In an at- 

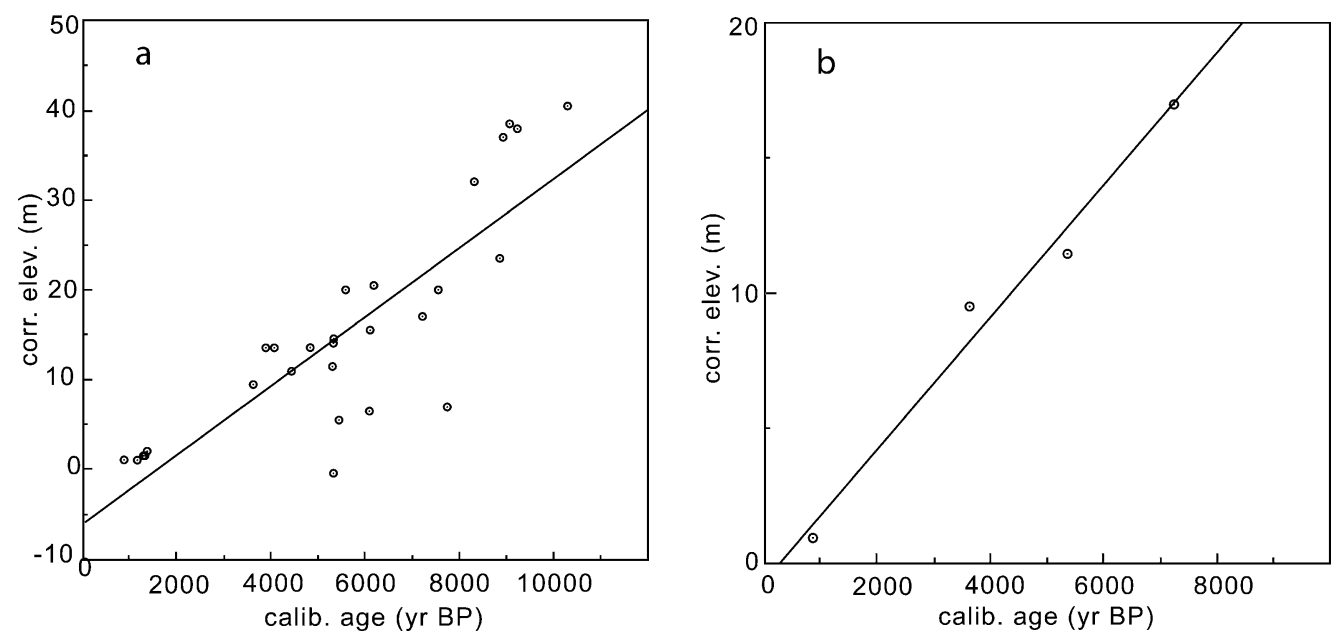

Fig. 4. Age/height plots for the Hengchun Peninsula. (a) All the sites listed in Table 1 (uplift rate: $3.8 \mathrm{~mm} \mathrm{yr}^{-1}, r^{2}=0.71$ ). (b) Sites distant from the Hengchun Fault (uplift rate: $2.4 \mathrm{~mm} \mathrm{yr}^{-1}, r^{2}=0.98$ ).

Fig. 4. Graphiques représentant l'altitude en fonction de l'âge. (a) Tous les sites mentionnés dans le Tableau 1 (taux de soulèvement : $3,8 \mathrm{~mm} \mathrm{an}^{-1}, r^{2}=0,71$ ). (b) Sites distants de la faille d'Hengchun (taux de soulèvement : $2,4 \mathrm{~mm} \mathrm{an}^{-1}, r^{2}=0,98$ ).

tempt to distinguish between net uplift and the effect of fault-related folding the age/height values for the four sites furthest from the fault, namely Yakoulu, Fantzuliao, KT1 and Shanhaili, were plotted separately. The resulting graph $\left(r^{2}=0.98\right)$ (Fig. $\left.4 b\right)$ indicates general uplift at about $2.5 \mathrm{~mm} \mathrm{yr}^{-1}$, so that the remaining $1.3 \mathrm{~mm} \mathrm{yr}^{-1}$ of uplift is attributable to deformation associated with the Hengchun Fault: the 'upbuckling' described by Liew and Lin [8].

\section{Seismic hazard}

An earlier attempt to identify zones of high potential seismicity on the basis of the neotectonic record proposed that the western fold-and-thrust belt was most at risk primarily because the geometry of its major fault structures was propitious both for strain accumulation and its seismic release [15]. The reasoning was that folding was driven by blind faults until their progressive rotation and steepening at the rear of the trench ruled out further slip. Support for the model comes from nascent folding in the coastal plain west of the fold-and-thrust belt $[4,12]$.

The new data refine the scheme by showing that deformation in the Central Range, or at any rate in its southern part, is partitioned between general uplift and localised folding. A plausible interpretation is that the former represents energy storage and the latter its release. To judge from the published cross-sections [2], the Hengchun fault in places dips $\sim 70^{\circ}$ E but rather than being inactive the structure serves as the locus of folding. Some seismicity is doubtless promoted by bedding slip but any residual stored energy is dissipated seismically in low angle reverse faults to the west.

This interpretation conflicts with the outcome of probabilistic analyses. Tsai et al. [14], for example, had concluded that the highest seismic risk was in the Northeast and East of Taiwan and that the lowest level of risk was displayed by the central range, the fold-and-thrust belt, and the North and South, with an intermediate level near the active faults in the western coastal plain and in the Southwest of the island. Needless to say the severity of risk within each zone depends on many additional factors. Thus $\mathrm{Wu}$ and Rau [18] have argued that blind thrusts in the fold-andthrust hills and the coastal plain are especially dangerous because they occur under populated urban areas; uplands prone to mass movement will evidently be more sensitive to uplift than lowlands.

Reliance on neotectonics in no way minimises the value of seismic analysis or geodesy; for, by identifying active zones, subsurface structures and fault polarity, these sources of data are an essential component of 
the assessment. What is at issue is the governing time scale. In many areas the recurrence interval between major events is measured in millennia, so that the historical evidence may lead one to underestimate the potential level of seismicity; on the other hand, geodetic measurements made over a few years give values for deformation which, though geometrically correct, can exaggerate the prevailing strain rate. The Hengchun Peninsula illustrates a third benefit of the long-term perspective: strain energy [3] may be stored across the entire accretionary prism but seismically released only where the available slip surfaces are favourably oriented and inclined. In sum, the proposed approach enables zones most susceptible to damaging seismicity to be identified and provides a rationale for the zoning of building regulations and emergency provision which is not compromised by inadequate instrumental or geodetic data.

\section{Acknowledgements}

C.V.-F. is am grateful to the Royal Society of London and the National Science Council, Taiwan, for support, Dr. P.J. Vita-Finzi for assistance in the field, Prof. T.K. Liu, National Taiwan University, for radiocarbon assays, and Prof. J. Angelier for comments on a draft of the paper.

\section{References}

[1] C.C. Biq, Dual trench structure in the Taiwan-Luzon region, Proc. Geol. Soc. China 15 (1972) 65-75.

[2] Central Geological Survey, 1/50000 geological map of Hengchun Peninsula (Sheet 69, 70, 72), Minist. Econ. Aff., Taipei, 1991.

[3] C.-P. Chang, T.Y. Chang, J. Angelier, H. Kao, J.-C. Lee, S.-B. Yu, Stress and strain field in Taiwan oblique convergent sys- tem: constrains from GPS observations and tectonic data, Earth Planet. Sci Lett. 214 (2003) 115-127.

[4] B. Fruneau, et al., Uplift of Tainan Tableland (SW Taiwan) revealed by SAR interferometry, Geophys. Res. Lett. 28 (2001) 3071-3074.

[5] C.S. Ho, Tectonic Evolution of Taiwan, Minist. Econ. Aff., Taipei, 1982.

[6] G.C.P. King, C. Vita-Finzi, Active folding in the Algerian earthquake of 10 October 1980, Nature 292 (1981) 22-26.

[7] O. Lacombe, F. Mouthereau, J. Angelier, B. Deffontaines, Structural, geodetic and seismological evidence for tectonic escape in SW Taiwan, Tectonophysics 333 (2001) 323-345.

[8] P.-M. Liew, C.-F. Lin, Holocene tectonic activity of the Hengchun Peninsula as evidenced in the deformation of marine terraces, Mem. Geol. Soc. China 9 (1987) 241-259.

[9] C.-H. Lin, Thermal modeling of continental subduction and exhumation constrained by heat flow and seismicity in Taiwan, Tectonophysics 324 (2000) 189-201.

[10] M.-T. Lin, Y.-B. Tsai, Seismotectonics in Taiwan-Luzon area, Bull. Inst. Earth Sci., Acad. Sin. 1 (1981) 51-82.

[11] N. Lundberg, D.L. Reed, C.-S. Liu, J. Lieske Jr., Forearc-basin closure and arc accretion in the submarine suture zone south of Taiwan, Tectonophysics 274 (1997) 5-23.

[12] F. Mouthereau, O. Lacombe, B. Deffontaines, J. Angelier, H.T. Chu, C.T. Lee, Quaternary transfer faulting and belt front deformation at Pakuashan (western Taiwan), Tectonics 18 (1999) 215-230.

[13] M. Stuiver, P.J. Reimer, Extended ${ }^{14} \mathrm{C}$ data base and revised Calib $3.0{ }^{14} \mathrm{C}$ calibration program, Radiocarbon 35 (1993) 215-230.

[14] C.-C. Tsai, C.-H. Loh, Y.T. Yeh, Analysis of earthquake risk in Taiwan based on seismotectonic zones, Mem. Geol. Soc. China 9 (1987) 413-446.

[15] C. Vita-Finzi, Deformation and seismicity of Taiwan, Proc. Natl Acad. Sci. 97 (2000) 11176-11180.

[16] C. Vita-Finzi, Buckle-controlled seismogenic faulting in peninsular India, Quat. Sci. Rev. 23 (2004) 2405-2412.

[17] C. Vita-Finzi, J.-C. Lin, Serial reverse and strike slip on imbricate faults: The coastal range of east Taiwan, Geology 26 (1998) 279-281.

[18] F.T. Wu, R.-J. Rau, Seismotectonics and identification of potential seismic source zones in Taiwan, Terr. Atmos. Ocean Sci. 9 (1998) 739-754.

[19] S.-B. Yu, H.-Y. Chen, L.-C. Kuo, Velocity field of GPS stations in the Taiwan area, Tectonophysics 274 (1997) 41-59. 